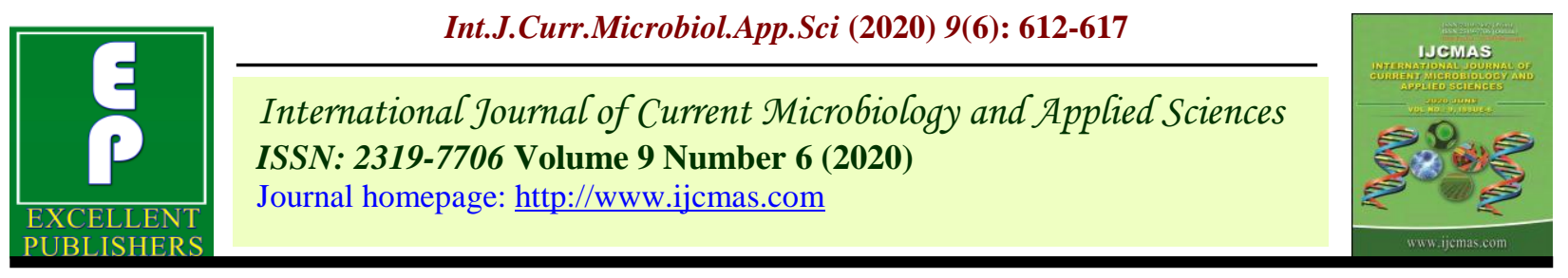

Original Research Article

https://doi.org/10.20546/ijcmas.2020.906.079

\title{
Socio Economics Characteristics of Maize Growers in Marathwada Region of Maharashtra State, India
}

\author{
R. F. Thombre ${ }^{1 *}$, K. V. Deshmukh ${ }^{2}$, R. V. Chavan ${ }^{3}$ and S. S. More ${ }^{4}$ \\ Department of Agricultural Economics, College of Agriculture Parbhani, \\ VNMKV, Parbhani-431 402 (MS), India \\ *Corresponding author
}

\begin{tabular}{|l|}
\hline Ke y w o r d s \\
maize growers \\
Multistage sampling \\
young and old \\
group farmers
\end{tabular}

\section{A B S T R A C T}

The present investigation was undertaken with a view to study the socio economic characteristics of maize growers in Marathwada Region of Maharashtra. The study was administered by selecting a sample of 180 respondents from 12 villages. Multistage sampling design was used in selection of district, taluka, village and maize growers. Relevant data on various aspects of socio economic status were illuminated using a pretested structured schedule and through personal interview method. Results revealed that 38.33 per cent of growers were of middle age, and the young and old group farmers were 31.11 per cent and 30.56 per cent respectively. With respect to educational level, higher secondary level was dominating with 28.33 per cent followed by secondary level education with 26.67 per cent. About 46.67 per cent of growers belonged to medium family size. In respect of occupational level of maize growers, most of farmers belonged to agriculture that was 82.22 per cent. The operational land holding of medium group was found to be maximum having 46.67 per cent and 70.00 per cent farmers have one bullock pair. The average number of livestock rearing of maize growers was 1.74 with 112.64 per cent coefficient of variation.

\section{Introduction}

Maharashtra is the one of the largest producer of maize in India. As concerned to Maharashtra state in the year 2014-15 area, production and productivity of maize was 1.08 Million ha, 2.2 Million tonnes and 2045 $\mathrm{kg} / \mathrm{ha}$. In Marathwada region maize was cultivated on 140800 ha and production and productivity was 321394 tonnes and $1095 \mathrm{kh} / \mathrm{ha}$ respectively during 2016-17 (kharif) An attempt had been made to study selected personal and socio economics characteristics of maize growers in the Marathwada region. It had been proven beneficial to know socio economics status of the growers to identify the challengers faced and establish their knowledge about improved 
farming practices. This in turn would help relevant stake holders to formulate appropriate policies which would give an added boost to the industry.

\section{Materials and Methods}

Multi stage sampling design was adopted for selection of districts, tehsils, villages and maize growers. In the first stage, two districts namely Aurangabad, and Jalna were purposely selected from Marathwada region as area and production of maize is concentrated in these districts. In the second stage, from each district two tehsils were selected on the basis of more area under maize cultivation. In third stage, list of predominant villages with respect to area under maize were obtained from selected tehsils. From each tehsils, three villages were selected purposely. In Aurangabad district the selected villages from Kannnad tehsils were namely Hatnur, Tapargaon and Nachanvell and from Sillod tahsil Modha (Bk),Andhari and Ghatnanadra were selected. In Jalna district from Bhokardhan tahsil Kedakheda ,Javkhed and Annva villages were selected and from Jafrabad tahsil Khaparkheda, Khasgaon and Janephal villages were selected. The list of maize growers for last one year was obtained from Gram Sewak and using simple random sampling technique, fifteen growers from each village were selected randomly. In this way, from two districts, one hundred eighty maize growers were selected for the present study. The data for the year 2019-20 was collected from maize growers with the help of pre-tested schedule through personal interview method.

\section{Results and Discussion}

Frequency distribution of maize growers with respect to socio economic status

Socio-economic characteristics of maize growers were estimated and are presented in Tables.

\section{Age (years)}

It was observed from the Table. 1 that the middle age farmers $(>40$ to $\leq 55)$ was 38.33 per cent, the young $(>25$ to $\leq 40)$ which was 31.11 per cent and old group farmers ( $>55$ to $\leq 70)$ was 30.56 per cent. Usman,( 2018) revealed that male farmers constituted the majority of the respondents and were mostly married, with a mean age of 38.34 and 44.02 years .

\section{Education (Level)}

Formal education plays an important role in capacity building, enhances comprehensive skill, and raises productivity ability of an individual. This in turn improves problem solving capacity of individuals. With view of above, education level of sample respondents was studied and presented in Table. 2

Results highlighted that, higher secondary level was dominating with 28.33 per cent followed by secondary level education with 26.67 per cent. Primary and college level education contributing 15.00 and 25.66 per cent respectively while illiteracy per cent was negligible accounting 4.44 per cent. Krishna et.al (2017) revealed that majority of the maize growers in Karimnagar district of Telangana were of middle age (47 yrs) and were educated up to primary school level. A vast majority of the respondents had medium family size and agriculture as main source of occupation.

\section{Family size}

Family size refers to the number of individuals in respective household. The family size of the respondents were studied and presented in Table 3. 
The family size of the farmers was divided into three categories on the basis of members in family as small, medium and large.

About 46.67 per cent of growers belonged to medium family size which was ranging from 5 to 7 members in a family followed by 28.33 per cent growers belonged to small family ranging from 2 to 4 members. About 25.00 per cent growers belonged to large family ranging from 8 to 10 members in a family.

\section{Occupation level}

The respondents were divided in 3 broad categories with respect to their occupation level. Findings are presented in Table 4. Results highlighted that majority of the respondents had farming (agriculture) as their source of occupation (82.22 per cent followed by services 10.00 and business very negligible having 7.78 per cent as their source of living.

\section{Operational land holdings (ha)}

Land holdings refers to total land area either cultivated or uncultivated which was in possession of the respondents at the time of data collection. As per the size of the land holdings, respondents were divided into 3 broad categories as in Table 5 .

In case of operational land holding medium group ranging from more than two hectares to four hectares ( $>2$ to $\leq 4 \mathrm{ha}$ ) was found to be maximum having 46.67 per cent,31.67 per cent farmers have less than less than two hectares of land and 21.67 per cent farmers comes under large holding category having more than 4 hectares' land.

\section{Soil type}

The fertility of soil is major aspect related directly productivity of crop and hence information regarding the type of soil were collected on general basis and presented in Table 6. Among the selected maize growers about 38.33 per cent were having light type soil, 36.67 medium soil and only 25.00 per cent growers were with heavy soils

\section{Fragmentation of land (no)}

The maize growers on the basis of the fragmentation of land were classified into 3 different categories on basis of number of land owned by maize growers in that particular village and presented in Table 7.Fragmentation of land was dominating with one fragment in which 58.89 per cent were distributed for maize farm.

\section{Farm distance from village}

In case of distance of farm from village, it was observed that 57.22 per cent farms were 0 to 2 kilometers away from the village, 24.44 per cent were more than $(>2$ to $\leq 4)$ away and only 18.33 per cent farms were ong away .i.e.. $>4$ to $\leq 6$ kilometers from village presented in Table 8 .

\section{Number of bullock pair}

The bullock is a animal power source for agriculture in Marathwada region for various operations and presented in Table 9. With respect to bullock pair 70.00 per cent farmers have one bullock pair, 2.78 per cent farmers having two bullock pairs while 27.22 per cent farmers having no bullock pair.

\section{Livestock's per farm}

Regarding the livestock, 19.44 per cent farmers rearing one livestock, 24.44 per cent farmers rearing two livestock, 14.44 cent farmers rearing three livestock, 10.00 per cent farmers having four livestock and 30.67 per cent farmers having no livestock, same is presented in Table 10. 
Table.1 Distribution of maize growers according to their age $\mathrm{N}=180$

\begin{tabular}{|c|c|c|}
\hline Particular & Frequency & Per cent \\
\hline 1.Young $>25$ to $<40$ & 56 & 31.11 \\
\hline 2.Middle $>40$ to $<55$ & 69 & 38.33 \\
\hline 3. Old $>55$ to 70 & 55 & 30.56 \\
\hline
\end{tabular}

Table.2 Distribution of maize growers according to education level (Score) N=180

\begin{tabular}{|c|c|c|}
\hline Particular & Frequency & Per cent \\
\hline 1. Illiterate level & 8 & 4.44 \\
\hline 2. Primary & 27 & 15.00 \\
\hline 3. Secondary & 48 & 26.67 \\
\hline 4. Higher secondary & 51 & 28.33 \\
\hline 5.College level & 46 & 25.56 \\
\hline
\end{tabular}

Table.3 Distribution of maize growers according to family size (No ) N=180

\begin{tabular}{|c|c|c|}
\hline Particular & Frequency & Per cent \\
\hline 1. Small (1 to 2$)$ & 51 & 28.33 \\
\hline 2. Medium (2 to 4$)$ & 84 & 46.67 \\
\hline 3. Large (4 \& above) & 45 & 25.00 \\
\hline
\end{tabular}

Table.4 Distribution of maize growers according to occupation level (Score) N=180

\begin{tabular}{|c|c|c|}
\hline Particular & Frequency & Per cent \\
\hline 1. Agriculture & 148 & 82.22 \\
\hline 2. Business & 18 & 10.00 \\
\hline 3. Services & 14 & 7.78 \\
\hline
\end{tabular}

Table.5 Distribution of maize growers according to operational land holding (Ha) N=180

\begin{tabular}{|c|c|c|}
\hline Particular & Frequency & Per cent \\
\hline 1. Small $(2$ to 4$)$ & 57 & 31.67 \\
\hline 2. Medium $(5$ to 7$)$ & 84 & 46.67 \\
\hline 3. Large (8 \& above) & 39 & 21.67 \\
\hline
\end{tabular}

Table.6 Distribution of maize growers according to type of soil N=180

\begin{tabular}{|c|c|c|}
\hline Particular & Frequency & Per cent \\
\hline 1.Light & 69 & 38.33 \\
\hline 2.Medium & 66 & 36.67 \\
\hline 3.Heavy & 45 & 25.00 \\
\hline
\end{tabular}


Table.7 Distribution of maize growers according to fragmentation of land N=180

\begin{tabular}{|c|c|c|}
\hline Particular & Frequency & Per cent \\
\hline 1.One & 106 & 58.89 \\
\hline 2.Two & 45 & 25.00 \\
\hline 3.Three & 29 & 16.11 \\
\hline
\end{tabular}

Table.8 Distribution of maize growers according to distance of farm from village N=180

\begin{tabular}{|c|c|c|}
\hline Particular & Frequency & Per cent \\
\hline 1.Near $\quad(>0$ to $\leq 2)$ & 103 & 57.22 \\
\hline 2.More $(>2$ to $\leq 4)$ & 44 & 24.44 \\
\hline 3.Long $(>4$ to $\leq 6)$ & 33 & 18.33 \\
\hline
\end{tabular}

Table.9 Distribution of maize growers according to number of bullock pair per farm N=180

\begin{tabular}{|c|c|c|}
\hline Particular & Frequency & Per cent \\
\hline 1.One & 126 & 70.00 \\
\hline 2 Two & 5 & 2.78 \\
\hline 3. Nill & 49 & 27.22 \\
\hline
\end{tabular}

Table.10 Distribution of maize growers according to number of livestock per farm N=180

\begin{tabular}{|c|c|c|}
\hline Particular & Frequency & Per cent \\
\hline 1.One & 35 & 19.44 \\
\hline 2.Two & 44 & 24.44 \\
\hline 3.Three & 26 & 14.44 \\
\hline 4. Four and more & 18 & 10.00 \\
\hline 5.Nill & 57 & 31.67 \\
\hline
\end{tabular}

Table.11 Mean, SD and CV of socio economic characteristics of Maize growers N=180

\begin{tabular}{|c|c|c|c|c|}
\hline \multirow{2}{*}{ Sr. No } & Particulars & \multicolumn{3}{|c|}{ Maize farm } \\
\cline { 3 - 5 } & & Mean & SD $( \pm)$ & CV \% \\
\hline $\mathbf{1}$ & Age of farmer (years) & 46.96 & 13.04 & $\mathbf{2 7 . 7 7}$ \\
\hline $\mathbf{2}$ & Educational level & 3.55 & 1.16 & 32.68 \\
\hline $\mathbf{3}$ & (three quantum score) & & & \\
\hline $\mathbf{4}$ & Family size (no) & 5.82 & 2.17 & 37.29 \\
\hline & Occupational level & 1.34 & 0.67 & 50.00 \\
\hline $\mathbf{5}$ & (three quantum score) & & & \\
\hline $\mathbf{6}$ & Type of soil & 2.41 & 0.62 & 25.73 \\
\hline & Total Land holding (ha) & 3.27 & 1.67 & 51.07 \\
\hline & Irrigated & 1.49 & 1.02 & 68.46 \\
\hline $\mathbf{7}$ & Rainfed & 1.59 & 0.88 & 55.35 \\
\hline $\mathbf{8}$ & Distance of farm from village $(\mathrm{km})$ & 1.57 & 0.76 & 48.41 \\
\hline $\mathbf{9}$ & Bullock pair (no) & 0.74 & 0.79 & 41.15 \\
\hline $\mathbf{1 0}$ & Livestock (no) & 1.74 & 0.49 & 66.22 \\
\hline & & & & 1.96 \\
\hline
\end{tabular}


Mean, S.D and COV of socio economic characteristics of maize grower

Mean, standard deviation and coefficient of variation of socio-economic characteristics of maize growers were calculated and are presented in Table 11. It was observed from the table that the average age of maize growers was 46.96 years. The coefficient of variation with respect to age was found to be 27.77 per cent. Educational level of farmers indicated 3.55 scores with 32.68 per cent coefficient of variation. With regards to family size the average size of family of maize growers was 5.82 or more than five and the coefficient of variation was 37.29 per cent. Occupational level was indicating 1.34 score with 50.00 per cent coefficient of variation.

The average land holding of maize growers was 3.27 hectares which came under medium size of holding. The coefficient of variation of land holding was found to be 51.07 per cent. Among land holding average irrigate and rainfed land holding of maize growers was 1.49 and 1.59 with 3.27 hectares with the coefficient of variation 68.46 and 55.35 per cent respectively. Fragmentation of land was 1.57 numbers on maize farm. It was clear that approximately fragmentation was at two locations. Distance of farm from village was 1.92 kilometers with respect to chickpea farm.
In case of bullock pair it was 0.74 numbers. The average number of livestock rearing of mize growers was 1.74 with 112.64 per cent coefficient of variation.

\section{References}

Krishna,M.,R.V.Chavan, Ritesh A.Chand and Vinodini. 2018. Socio Economic Characteristics of Maize Growers in Karimnagar District of Telangana State, India. Int.J.Curr.Microbiol.App.Sci. 7(12): 1915-1920.

Mohan Paramkusam and Sivaramane.2016. A socio-economic status of maize farmers of Telangana and Andhra Pradesh, India. Indian Journal of Economics and Development, Vol 4 (6),: 2320-9828.

Sindhuja, P. and Asokhan, M. 2018. Socio Economic Characteristic of Dryland Farmers in Tiruppur District, India - An Gender Analysis. Int.J.Curr.Microbiol.App.Sci. 7(03): 5458.

Usman, J., 2018 .Comparative Analysis of Socio-Economic Determinants of Rainfed Maize Production in Jaunpur District Uttar Pradesh, India and Adamawa State, Nigeria International Journal of Advances in Agricultural Science and Technology, Vol.5 (2), : 40-54.

\section{How to cite this article:}

Thombre. R. F., K. V. Deshmukh, R. V. Chavan and More. S. S. 2020. Socio Economics Characteristics of Maize Growers in Marathwada Region of Maharashtra State, India. Int.J.Curr.Microbiol.App.Sci. 9(06): 612-617. doi: https://doi.org/10.20546/ijcmas.2020.906.079 